Viso: Cadernos de estética aplicada

Revista eletrônica de estética

ISSN 1981-4062

$N^{\circ} 27$, jul-dez/2020

http://www.revistaviso.com.br/
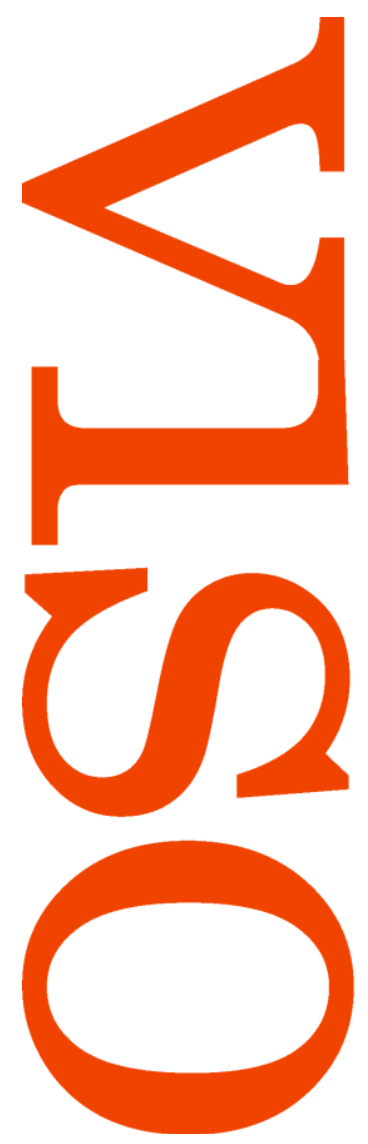

\title{
Para além das utopias: \\ Rancière e as imagens heterotópicas
}

Daniela Cunha Blanco

Universidade de São Paulo (USP)

São Paulo (SP) 


\section{RESUMO}

Para além das utopias: Rancière e as imagens heterotópicas

Partindo da análise de algumas imagens da arte contemporânea pretendemos dar a ver a impossibilidade do pensamento das relações entre arte e política sob a categoria de utopia e, com isso, propor que a concepção de partilha do sensível, de Jacques Rancière, daria mais conta de pensar as capacidades de resistência da arte. Pretendemos pensar o poder disruptivo da arte a partir da noção de heterotopia, tal qual pensada por Michel Foucault; termo ao qual Rancière remete-se em sua crítica à noção de utopia, sem aprofundá-lo. Em oposição ao que denominamos de imagens utópicas, procuraremos construir a figura de uma imagem heterotópica, na qual não se trata de pensar um engajamento político no sentido de desvelar a verdade aos espectadores, mas, antes, de operar pequenos desvios e fendas na ordenação comum das coisas. Trata-se de ver pequenos lampejos, fugazes e frágeis, tais quais aqueles pensados por Georges Didi-Huberman, cujo pensamento da persistência do olhar será apresentado em diálogo com Rancière.

Palavras-chave

heterotopia; partilha do sensível; imagem; Jacques Rancière

\section{ABSTRACT}

\section{Beyond Utopias: Ranciere and the Heterotopic Images}

Based on the analysis of some images of contemporary art, we intend to show the impossibility of thinking about the relations between art and politics under the category of utopia and, with this, we propose that Jacques Rancière's conception of distribution of the sensible would give more account to think about the resistence of art. We intend to think about the disruptive power of art from the notion of heterotopy, as thought by Michel Foucault; term to which Rancière refers in his criticism of the notion of utopia, without going into it further. In opposition to what we call utopian images, we will try to construct the figure of a heterotopic image, in which it is not a matter of thinking about a political commitment in order to reveal the truth to the spectators, but, rather, to operate small deviations and cracks in the common ordering of things. It is about seeing small flashes, fleeting and fragile, such as those thought by Georges Didi-Huberman, whose thought of the persistence of the gaze will be presented in dialogue with Rancière.

Keywords

heterotopia; distribution of the sensible; image; Jacques Ranciere 


\section{CUNHA BLANCO, Daniela . "Para além das utopias:}

Rancière e as imagens heterotópicas". Viso: Cadernos de estética aplicada, v. 14, n²7 (jul-dez/2020), p. 92127.

DOI: $10.22409 / 1981-4062 / v 27 i / 362$

Aprovado: 29.10.2020. Publicado: 28.12.2020.

(C) 2020 Daniela Cunha Blanco. Esse documento é distribuído nos termos da licença Creative Commons Atribuição-NãoComercial 4.0 Internacional (CC-BY-NC), que permite, exceto para fins comerciais, copiar e redistribuir o material em qualquer formato ou meio, bem como remixá-lo, transformá-lo ou criar a partir dele, desde que seja dado o devido crédito e indicada a licença sob a qual ele foi originalmente publicado.

Licença: http://creativecommons.org/licenses/by-nc/4.0/deed.pt_BR

Accepted: 29.10.2020. Published: 28.12.2020.

(C) 2020 Daniela Cunha Blanco. This document is distributed under the terms of a Creative Commons Attribution-NonCommercial 4.0 International license (CC-BY-NC) which allows, except for commercial purposes, to copy and redistribute the material in any medium or format and to remix, transform, and build upon the material, provided the original work is properly cited and states its license.

License: http://creativecommons.org/licenses/by-nc/4.0/ 


\title{
Introdução
}

Jacques Rancière ${ }^{1}$ afirma que as relações entre estética e política devem ser pensadas como constitutivas, como se houvesse, na base da política, uma estética, e nos fundamentos desta, uma política. Há, com isso, um deslocamento do pensamento que afirma um processo de estetização da vida, cujo efeito seria a transformação da arte em mais uma expressão da lógica do capital. Se partirmos da perspectiva de que estética e política estão imiscuídas uma na outra desde sempre, recusamos a afirmação de que, por algum processo teleológico ou histórico, elas tenham se misturado e, por isso, perdido suas capacidades críticas. A questão sobre os aspectos políticos da arte, ou sobre a possibilidade de uma arte que resista, deve ser recolocada a partir de tal perspectiva. Para Rancière, a arte opera o mesmo que os enunciados políticos: reconfigurações dos espaços e dos tempos, redisposição das linhas que separam os campos de saberes, redistribuição "dos papeis, dos territórios e das linguagens em resumo, desses sujeitos políticos que recolocam em causa a partilha já dada do sensível". ${ }^{2}$ A arte e a política, teriam, assim, em comum, a capacidade de determinar modificações no curso comum das coisas, nos modos de percepção sensível que configuram nossos modos de vida, que reconfiguram a partilha do sensível - compreendida como

\begin{abstract}
um recorte dos tempos e dos espaços, do visível e do invisível, da palavra e do ruído que define ao mesmo tempo o lugar e o que está em jogo na política como forma de experiência. A política ocupa-se do que se vê e do que se pode dizer sobre o que é visto, de quem tem competência para ver e qualidade para dizer, das propriedades do espaço e dos possíveis do tempo. ${ }^{3}$
\end{abstract}

A partir da noção de partilha do sensível e da relação intrínseca entre estética e política que apresenta, nosso intuito é colocar a questão da possibilidade de uma imagem que resista à ordenação comum das coisas, que desloque a configuração dada pela lógica do capital. Daremos a ver como a 
possibilidade de resistência da arte, para Rancière, está diretamente associada ao que o autor denomina de modelos de eficácia da arte. Apresentando os três modelos pensados pelo autor - ético, representativo e estético - pretendemos mostrar como os dois primeiros apareceriam nas imagens daquilo que Rancière denomina de arte engajada, enquanto o último será apresentado como o modelo possível para tempos nos quais a utopia se mostra como categoria esgotada.

Partindo das análises que Rancière ${ }^{4}$ faz de algumas imagens do campo das artes visuais, no livro 0 espectador emancipado, propomos aproximar a ideia de arte engajada da noção de imagem utópica. Dada a inoperância dessas imagens, apresentaremos um outro modo de pensamento de resistência política da arte construindo a figura de uma imagem heterotópica que, em oposição às ideias de conscientização e de projeto, seriam compostas por pequenos lampejos, por mínimos desvios e reconfigurações sensíveis tais quais aparecem na imagem dos vaga-lumes, de Georges DidiHuberman. $^{5}$

Se Rancière nos dá as ferramentas para pensar a inoperância da utopia e da arte engajada, e afirma que as configurações da política e da arte "são, portanto, heterotopias mais do que utopias" ${ }^{\prime 6}$, não nos dá a ver uma análise mais profunda do que compreende sob tal termo. ${ }^{7}$ Faremos, assim, uma breve aproximação do modo com que Michel Foucault ${ }^{8}$ pensa a heterotopia, tomando de empréstimo, assim, tal noção para pensarmos a possibilidade de resistência da arte e das imagens em um cenário de inoperância da utopia. Nosso intuito é aproximar a noção de heterotopia à noção de partilha do sensível rancieriana. Didi-Huberman, por sua vez, será aproximado do pensamento de Rancière com o intuito de marcar uma necessidade da persistência do olhar, da insistência da percepção para ver uma outra configuração possível do mundo sensível que nos rodeia. 


\section{A inoperância da utopia e da arte engajada}

A partir do entrelaçamento entre estética e política, tal qual sintetizado na noção de partilha do sensível, Rancière ${ }^{9}$ irá operar, no livro $O$ espectador emancipado, um deslocamento de certas categorias do pensamento da arte. Interessado em pensar o modo com que uma determinada arte se apropria do pensamento crítico com o intuito de afirmar-se como arte engajada ou arte ativista, o autor aponta as aporias de uma pretensão política reduzida a processos de conscientização do espectador. Nas diversas expressões artísticas cuja tendência geral é o pensamento do engajamento político a partir da abordagem de temas do âmbito social que devem ter sua verdade desvelada ao espectador, há, afirma Rancière, um mesmo pressuposto, um mesmo modo de pensamento que remete a uma certa identificação da arte cuja origem está no passado: uma "imposição ativa de uma forma à matéria passiva, e esse efeito coadunava com uma hierarquia social na qual os homens de inteligência ativa dominavam os homens da passividade material". ${ }^{10}$ Há, portanto, a separação de duas inteligências. $O$ autor retoma as ideias tratadas no livro $O$ mestre ignorante, no qual dá a ver que a pedagogia é pensada como uma progressão de acúmulo de conhecimento, tendo como consequência a impossibilidade apresentada ao aluno de alcançar a posição do mestre. As posições daquele que ensina e daquele que aprende seriam, assim, fixas, nunca intercambiáveis, pois definidas por uma distância instransponível do acúmulo de conhecimento incessante, uma distância que marca duas progressões que caminham juntas, mas sem que nunca partam do mesmo ponto. 0 conhecimento que os separa é como uma série de hieróglifos cuja mensagem é desvelada pelo mestre diante dos olhos do aluno. Um saber fixo e imutável, inacessível ao aluno por sua incapacidade de decifrá-lo autonomamente. Tal operação, que considera a distância intransponível como "a condição normal de toda comunicação"11, é, segundo Rancière, retomada pelo pensamento artístico da arte engajada ou ativista. A arte teria, assim, vestido a fantasia do pedagogo embrutecedor, para quem interessa "a lógica da transmissão direta e fiel: há 
alguma coisa, um saber, uma capacidade, uma energia que está de um lado - num corpo ou numa mente - e deve passar para o outro". ${ }^{12}$

As imagens produzidas a partir desse modo de pensamento estariam, ainda, associadas a uma ideia que alimentou tanto o debate estético quanto o debate político por muito tempo: o conceito de utopia. Andreas Huyssen ${ }^{13}$ aponta para o fato de que a utopia modernista surge como uma ideia de reconstruir a Europa devastada pela Guerra através da arquitetura e das artes, acreditando nisso como parte de um processo de renovação social e política. Imbuído de ideias de resistência e de contracultura, o modernismo vanguardista acreditava na capacidade da arte de transformar as estruturas políticas e sociais A utopia, nesse sentido, surgia como a ideia de um outro lugar, de um espaço-tempo inexistente ao qual se poderia chegar trilhando o caminho da modernização. 0 papel da arte na realização da utopia era o de moldar não apenas as cidades, as formas artísticas, a percepção, mas a própria capacidade crítica das massas, o próprio modo de pensamento dos indivíduos que, embotados pelas aparências enganadoras do capital, seriam conscientizados dos mecanismos ilusórios e passariam a agir politicamente. A figura da utopia surge, assim, como um ponto de chegada de um processo histórico no qual a ação é pensada em direta oposição à passividade daqueles que estariam emaranhados nos mecanismos de alienação do capital. Figuras da utopia que, nas palavras de Michel Foucault, são

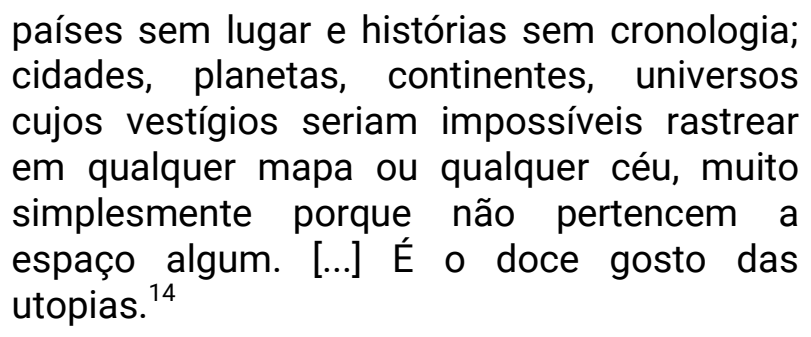

Desse modo, as imagens da arte engajada, tal qual pensadas por Rancière, serão aqui chamadas de imagens utópicas. Pretende-se, com isso, caracterizar os modelos de eficácia da arte em relação com a política, dando a ver um movimento de 
mudança que teria alterado o sentido político da arte, não mais em termos utópicos, mas em termos de heterotopia, como caracterizaremos a frente.

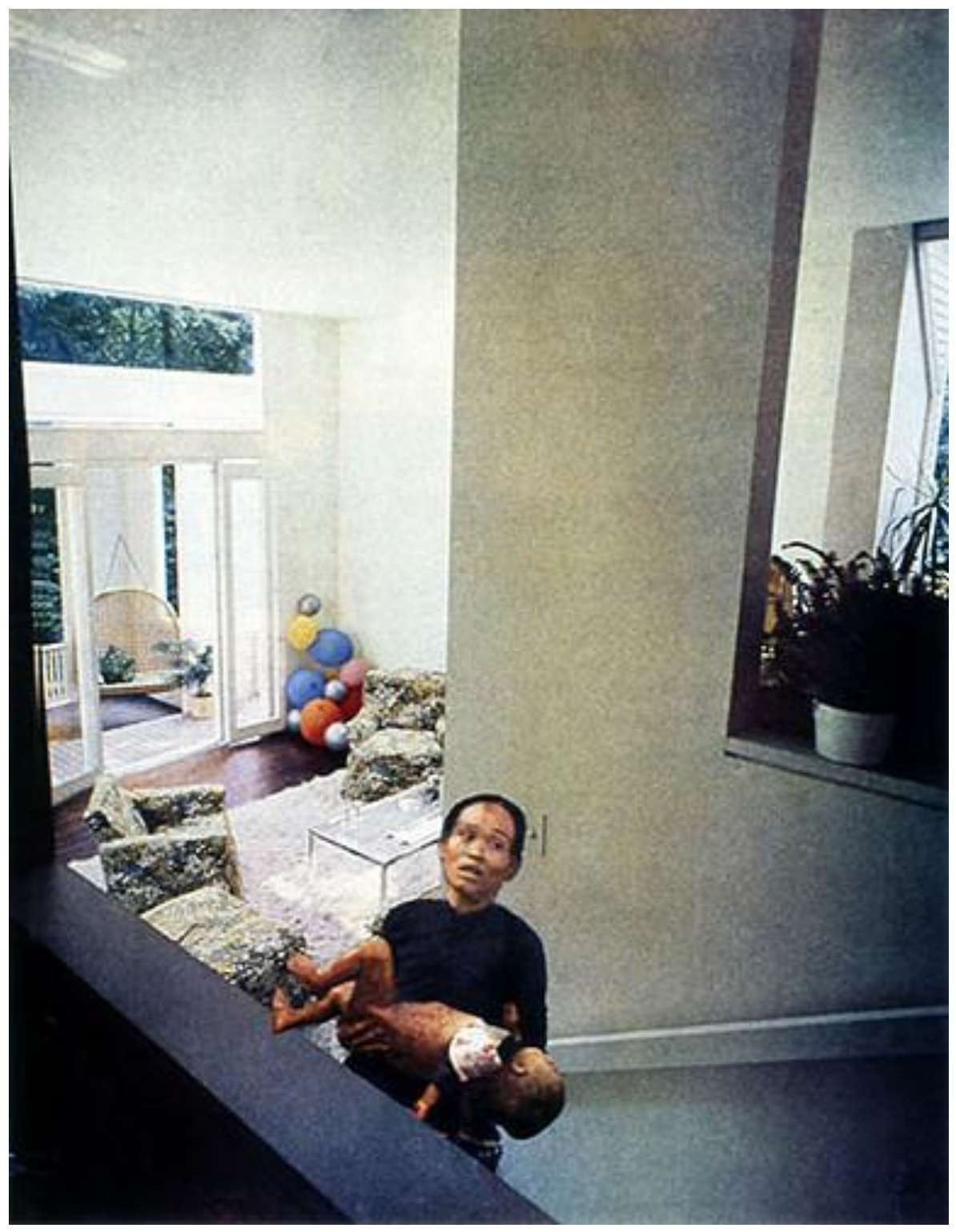

Martha Rosler, Balloons, House Beautiful: Bringing the War Home, 1967.

Rancière afirma que a arte engajada opera a partir de dois modelos de eficácia diversos, o da mediação representativa e o da imediatez ética. Ambos os modelos se fundamentam em uma lógica da causa e do efeito, como se fosse possível prever, nas intenções do artista, um resultado ou eficácia da ação do espectador. Vejamos esses dois modelos operando a partir das análises das imagens realizada pelo autor. 
Há, para Rancière, um pensamento da arte pautado em uma pedagogia da mediação representativa, na qual "a arte é considerada política porque mostra os estigmas da dominação, porque ridiculariza os ícones reinantes". ${ }^{15}$ É isso que está em jogo, na interpretação feita por Rancière, da série de fotomontagens Bringing the War Home: House Beautiful, realizada por Martha Rosler entre 1962 e 1970, no contexto da Guerra do Vietnã. Em uma delas, denominada Balloons, balões infláveis coloridos preenchem o canto da sala de uma típica casa americana, cujo conforto é sobreposto pela imagem de um vietnamita que segura um bebê morto nos braços. Rancière afirma que

a conexão das duas imagens devia produzir dois efeitos: a consciência do sistema de dominação que ligava a felicidade doméstica americana à violência da guerra imperialista, mas também um sentimento de cumplicidade culpada com aquele sistema. Por um lado, a imagem dizia: eis a realidade oculta que vocês não sabem ver, vocês precisam tomar conhecimento dela e agir de acordo com esse conhecimento. Mas não há evidências de que o conhecimento de uma situação provoque o desejo de mudá-la. É por isso que a imagem dizia outra coisa. Ela dizia: eis a realidade óbvia que vocês não querem ver, porque vocês sabem que são responsáveis por ela. ${ }^{16}$

Para Rancière, esse choque entre elementos heterogêneos operado pela fotomontagem de Martha Rosler parte da ideia embrutecedora do pensamento, aquela que pressupõe que exista um certo tipo de inteligência incapaz de realizar, por si só, a conexão entre o conforto da vida americana e a guerra perpetuada por seu país. O choque desses elementos, na imagem, serviria, assim, como um disparador para a conscientização em relação àquilo que estaria velado pela lógica do capital, por um lado, e, por outro, a partir da imputação de um sentimento de culpa, serviria também como um disparador para a ação política. 


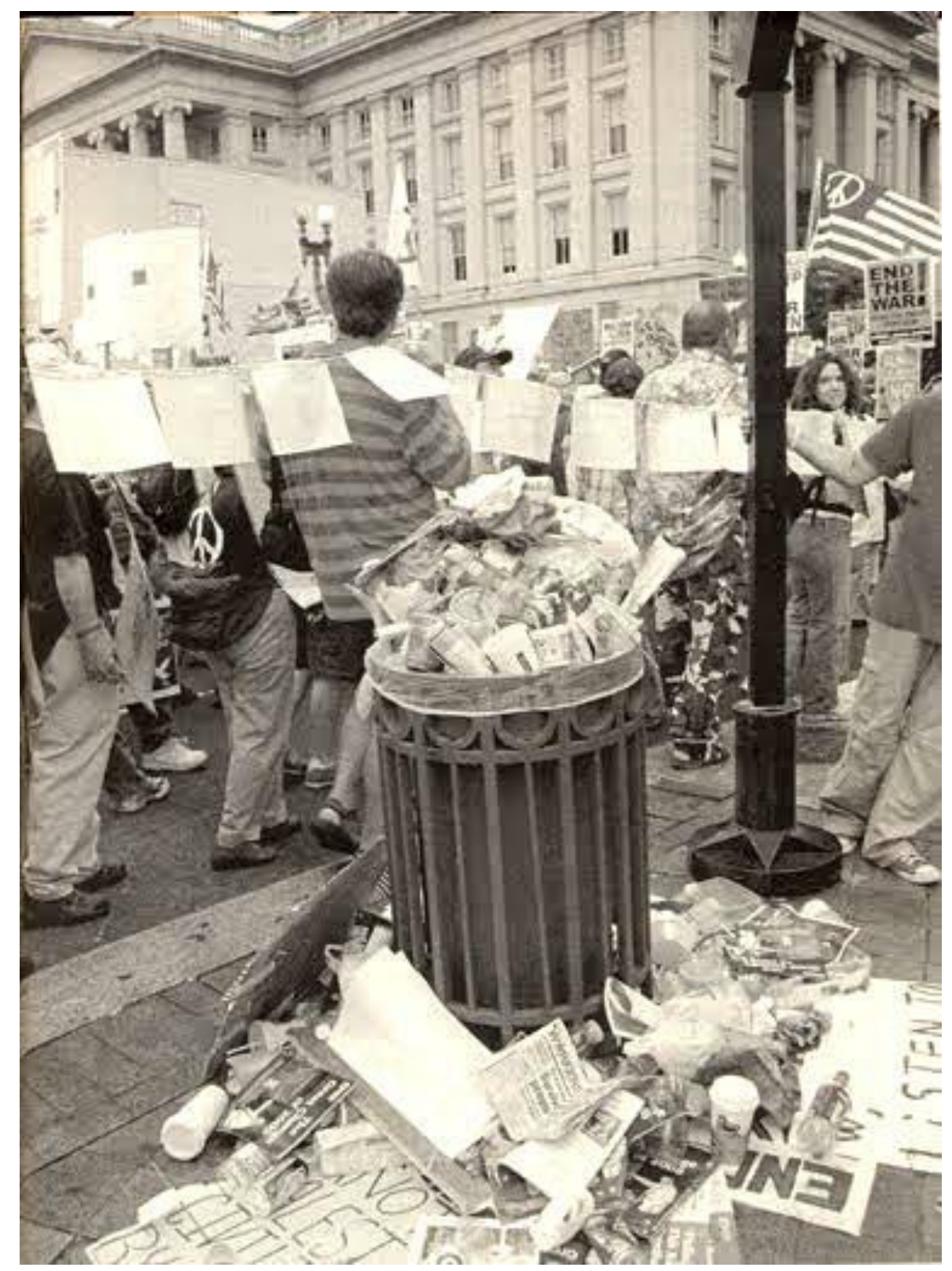

Josephine Meckseper, Sem título, 2005.

Tal operação do choque como impulso para a transformação política, continua Rancière ${ }^{17}$, aparece, ainda, nas fotografias de Josephine Meckseper, criadas no início dos anos 2000 em resposta ao anúncio da invasão ao Iraque feita pelo então presidente americano George W. Bush. Em uma delas, vemos, no segundo plano da imagem, uma manifestação política, com dezenas de pessoas que marcham carregando cartazes e bandeiras, posicionando-se contra a anunciada invasão ao Iraque. Enquanto o primeiro plano é ocupado por uma lata de lixo transbordando de cartazes, latas de cerveja e embalagens de fast food. Como afirma Rancière ${ }^{18}$, a imagem criada por 
Meckseper prescindiu da técnica da colagem empregada por Martha Rosler, mas utilizou-se do mesmo procedimento do choque entre elementos heterogêneos com o intuito de apontar o vazio político de tais manifestações. A fotografia sugere, na interpretação de Rancière, "que a marcha deles é uma marcha de consumidores de imagens e indignações espetaculares". ${ }^{19}$ Assim, continua o autor, essas coisas que aparentemente se contradizem na imagem - o consumo e o engajamento político -, são reunidas pela artista com 0 intuito de mostrar que "pertencem à mesma realidade" e que "o radicalismo político também é um fenômeno de moda jovem". ${ }^{20}$

Ambas as imagens, a de Martha Rosler e a de Josephine Meckseper, fundamentam-se em um modelo de eficácia que pretende dar a ver uma representação da realidade capaz de desvelar a mentira das aparências de nossas vidas. Modelo baseado na oposição entre aparência e realidade, entre aquilo que uma determinada inteligência é capaz de enxergar e cujo acesso é negado a outra inteligência. Para Rancière, esse pensamento crítico operado pela arte engajada ou arte ativista sustenta a relação desigual entre aqueles que sabem e aqueles que ignoram. Rancière afirma que o artista crítico ou engajado

\begin{abstract}
sempre se propõe produzir o curto-circuito e o choque que revelam o segredo ocultado pela exibição das imagens. Em Martha Rosler, o choque devia revelar a violência imperialista por trás da exposição feliz dos bens e das imagens. Em Josephine Meckseper, a exibição das imagens mostra-se idêntica à estrutura de uma realidade em que tudo é exposto no modo da exposição comercial. Mas o objetivo é sempre mostrar ao espectador o que ele não sabe ver $\mathrm{e}$ envergonhá-lo porque ele não quer ver. ${ }^{21}$
\end{abstract}

Opondo, assim, realidade e aparência, consciência e ignorância, atividade e passividade, a arte engajada, tal qual compreendida por Rancière, acaba por configurar uma partilha do sensivel na qual as posições nunca são intercambiáveis, na qual a divisão entre as inteligências impossibilita uma reconfiguração espaçotemporal, uma reconfiguração política dos modos de vida. 
Mas há, ainda, como dissemos, um outro modelo de eficácia da arte engajada: o da imediatez ética. Segundo Rancière, trata-se de um pensamento no qual "os dispositivos da arte [...] apresentam-se diretamente como propostas de relações sociais" ${ }^{22}$, ideia associada pelo autor ao pensamento de Nicolas Bourriaud sob o nome de estética relacional. ${ }^{23}$ As imagens construídas a partir de tal modelo expressariam uma certa ideia de comunidade que Rancière aponta como consensual, ou seja, um modo de viver juntos no qual as visibilidades dos agentes envolvidos na disputa política seriam unívocos. Não se trata de pensar o consenso como mera divergência de opiniões, antes, trata-se de pensá-lo como um "acordo entre sentido e sentido, ou seja, entre um modo de apresentação sensível e um regime de interpretação de seus dados". ${ }^{24}$ O consenso surge, assim, como um modo de pensamento a partir do qual criam-se imagens de um mundo homogêneo, um mundo cuja imagem de comunidade única é aquela da construção dos vínculos sociais de uma sociedade harmoniosa. ${ }^{25}$ 

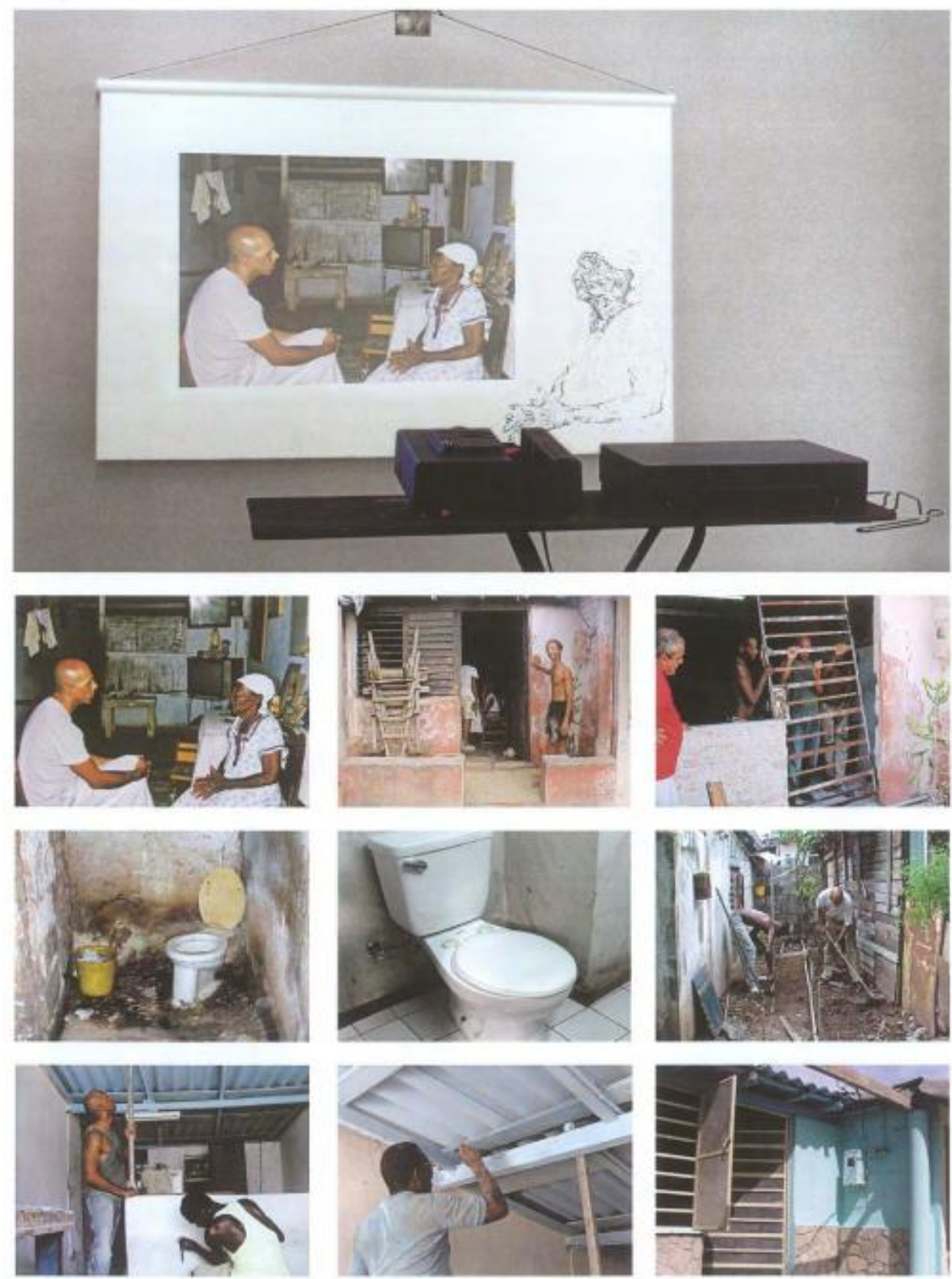

René Francisco, A la ca(sz)a de Rosa, 2003.

Para Rancière, é esse modelo de eficácia ética que opera na obra A la ca(sz)a de Rosa, de René Francisco, apresentada na Bienal de São Paulo de 2004. Durante uma residência artística, na qual realiza uma pesquisa das condições de vida em um bairro carente da cidade de Havana, René decide, com um grupo de outros artistas, reformar a casa de uma idosa moradora do bairro. A imagem que tornava a ação visível mostrava, nas palavras de Rancière, "uma tela de tule sobre a qual estava impressa a imagem de perfil da mulher voltada para um monitor no qual um vídeo exibia os artistas trabalhando como pedreiros, pintores ou encanadores". ${ }^{26}$ Há 
um movimento de saída da arte para o mundo fora das paredes dos museus, uma saída em direção às formas de vida, às questões sociais e políticas. Mas há, também, para que essa saída possa ser exposta, um retorno ao espaço do museu. Rancière aponta como essa tendência da arte contemporânea a "sair dos lugares da arte", intervindo no real, "só ganha sentido quando sua exemplaridade é manifestada no espaço do museu". ${ }^{27} \mathrm{~A}$ ação dos artistas que vão à periferia para realizar uma ação no mundo real surge, no interior do museu, como uma ação exemplar. Essa exemplaridade da ação diz à arte que ela deve sair de seus espaços próprios, que ela deve ir ao mundo real e retornar ao interior do museu. Essa arte que deixou de se preocupar com as formas plásticas para criar formas de relações apresenta-se, na visão de Rancière ${ }^{28}$, como uma operação que antecipa seu próprio efeito. Tudo se passa como se a construção da casa realizasse, pela exibição da transformação de uma vida exemplar, a reconstrução de um vínculo social perdido.

Nesse modelo de eficácia ética, há, diz Rancière, uma imediata "identidade antecipada entre a apresentação de um dispositivo sensível de formas, a manifestação de seu sentido e a realidade encarnada desse sentido". ${ }^{29}$ Consenso, pois, de uma comunidade tanto no âmbito político quanto comunicacional. Não há, na exibição da obra ou da intervenção, nenhuma outra interpretação possível, nenhuma outra experiência estética ou política, além daquela já prevista e antecipada na ação e que será, posteriormente, transformada em exemplo na imagem apresentada no museu.

Andrea Soto Calderón, em sua leitura de Rancière, afirma que a crítica operada por esses modelos de eficácia da arte expressa

uma dupla suspeita: por um lado, o receio das aparências enquanto aparências, o mundo sensível que elas geram; por outro, seu caráter falacioso, por não poder coincidir com o verdadeiro, como uma espécie de ilusão subjetiva que não pode evitar ser uma distorção da verdade. Diferente das verdades eternas que se buscava descobrir através da razão, o mundo das aparências se apresenta 
como contingente, arbitrário e potencialmente perigoso para aqueles que buscam a verdade. $^{30}$

Calderón afirma ainda que esse pensamento crítico aponta como única saída, diante de suas suspeitas, que o pensamento se oponha e combata as aparências. É esse mecanismo que vemos funcionar nas imagens aqui trabalhadas: trata-se de uma inserção da razão causal na imagem com o intuito de não permitir que as aparências possam expressar ou operar algum desvio.

Para Rancière, a arte não é política porque tematiza sobre questões sociais fulcrais para o debate político, tampouco porque operaria o espectador a uma conscientização sobre os processos de dominação que o levariam à ação, mas, antes, porque expressa um modo de pensamento que configura e determina nossos modos de sentir e perceber o mundo. A arte engajada dá a ver uma certa ideia de espectador que aparece sempre em oposição ao artista ou à arte: ela opõe o saber da arte à ignorância do espectador, a aparência enganadora da lógica de dominação à realidade desvelada, a atividade do artista criador à passividade daquele que apenas olha. Rancière aponta, assim, essa tendência da arte engajada:

Geralmente consideram ponto pacífico certo modelo de eficácia: a arte é considerada política porque mostra os estigmas da dominação, porque ridiculariza os ícones reinantes ou porque sai de seus lugares próprios para transformar-se em prática social etc. [...] Supõe-se que a arte nos torna revoltados quando nos mostra coisas revoltantes, que nos mobiliza pelo fato de mover-se para fora do ateliê ou do museu, e que nos transforma em oponentes do sistema dominante ao se negar como elemento desse sistema. $^{31}$

Podemos pensar como esses dois modelos de eficácia (ética e representativa), que ligam a arte à política a partir da ideia do engajamento, estão no cerne da noção de utopia e, portanto, da noção de imagens utópicas aqui construída. Trata-se, afinal, em ambos os modelos de eficácia da arte apontados por Rancière 
como bases da arte engajada, de um pressuposto de que a arte seria capaz de desvelar a verdade por trás dos mecanismos de alienação do capital. Do lado da inteligência e da consciência, estariam, assim, os artistas, e do lado da ignorância, os espectadores. Mesmo que se passe de uma ideia de revolução como progresso da consciência em direção a um fim último para uma outra ideia de transformação social mais pontual, como na intervenção realizada por René Francisco, ainda persistem as oposições entre realidade e aparência, atividade e passividade, consciência e ignorância. Oposições que alimentaram e que foram alimentadas pela noção de utopia.

Desse modo, para Calderón, o intuito de Rancière é questionar "quais são os pressupostos que conduziram a declarar-se que as imagens não estão aptas para criticar a realidade". ${ }^{32}$ Tratase, portanto, de pensar um modo de liberar as imagens e as aparências em relação aos modelos de eficácia ético e representativo. Nas palavras de Calderón, "Rancière propõe deixar de compreender as aparências como ilusão e começar a compreender a aparência como diferença, uma dissimetria criativa e que é sempre litigiosa". ${ }^{33}$

É isso que está em jogo no modelo de eficácia estético da arte - que Rancière ${ }^{34}$ propõe em oposição ao representativo e ao ético -, cuja operação é a da "suspensão de qualquer relação direta entre a produção das formas da arte e a produção de um efeito determinado sobre um público determinado". ${ }^{35}$ A eficácia estética da arte nada tem a ver com as intenções do artista e tampouco pressupõe qualquer tipo de ordenação ou configuração espaço-temporal específica para que ocorra. Não pressupõe regras e prescinde de qualquer hierarquia entre os saberes. Só ocorre, enfim, quando se suspende todo desejo e pretensão de um efeito de ordem causal. A eficácia estética, como diz Rancière, "não produz nenhuma correção dos costumes nem nenhuma mobilização dos corpos. Já não se dirige a nenhum público específico, mas ao público anônimo indeterminado dos visitantes de museus e dos leitores de romances" ${ }^{36}$ As formas artísticas não estão mais conectadas a fins sociais específicos e, se podem responder politicamente, 
ou seja, se podem acolher formas de pensamento que resistam e desviem das formas dominantes, é justamente por pertencer a esse sensório comum desprovido de fins.

Para compreender o sentido do que pode ser uma imagem resistente, para Rancière, faz-se necessário analisar o que 0 autor compreende sob o nome de imagem. No livro 0 destino das imagens, Rancière afirma que, no modelo de eficácia estética, "a imagem não é mais a expressão codificada de um pensamento ou de um sentimento. Não é mais um duplo ou uma tradução, mas uma maneira como as próprias coisas falam e se calam". ${ }^{37}$ Trata-se de compreender que a imagem não é uma fantasia que recorta e representa um pedaço do mundo real; antes, ela é a própria configuração do real. É a isso que se refere o autor quando afirma que as imagens operam um regime de imagéité, "isto é, um regime de relações entre elementos e entre funções". ${ }^{38}$ As operações das imagens colocam em relação o visível e o invisível, o dizível e o indizível e, ainda, "o visível e sua significação, ou a palavra e seu efeito" ${ }^{39}$ É, assim, nesse sentido que a imagem pode resistir a algo, que pode ser pensada como política. A ordem do visível e do dizível, afinal, não pertencem a um mundo separado que seria próprio à arte; antes, essa ordem é justamente aquela que configura nossos modos de vida, determinando quais sujeitos estão ou não aptos a falar, quais questões são visíveis e quais permanecem sob a invisibilidade.

Para Rancière, quando se muda a perspectiva a partir da qual se pensam as relações entre arte e política, entre estética e política, deve-se modificar, também, o pensamento da resistência, que não poderá mais ser compreendida sob a figura da utopia. Os diversos entrelaçamentos possíveis entre arte e política - que vão muito além daqueles expressos na arte engajada - impõem a necessidade de deslocar o pensamento da arte em relação aos moldes utópicos. Não se trata mais do pensamento de um projeto estético-político que, ao ser colocado em ação, levaria a sociedade a um progresso cujo fim seria um espaço-tempo de um sonho realizado ou de uma totalidade funcional que teria sido já postulada. Não se trata 
mais, portanto, de pensar a categoria de utopia - que até a década de 1970 estava diretamente associada aos poderes disruptivos da arte em relação à configuração política -, afinal, esta não dá mais conta de expressar as operações da arte e de relacionar a estética à política. Como afirma Rancière,

Do ponto de vista que nos ocupa, o das reconfigurações do sensível comum, a palavra utopia carrega duas significações contraditórias. A utopia é o não-lugar, o ponto extremo de uma reconfiguração polêmica do sensível, que rompe com as categorias da evidência. Mas também é configuração de um bom lugar, de uma partilha não polêmica do universo sensível, onde o que se faz, se vê e se diz se ajustam exatamente. ${ }^{40}$

A utopia, assim, expressaria uma certa ideia de um tecido harmonioso da sociedade, no qual cada indivíduo teria seu papel e função definidos, no qual cada espaço e cada tempo seriam ocupados segundo uma hierarquia e uma ordenação pré-estabelecidas. Um espaço utópico é, para Rancière, a expressão do exato oposto da política ou de uma partilha do sensível política. Afinal, a política é "o embaralhamento da fronteira entre os que agem e os que olham, entre indivíduos e membros de um corpo coletivo". ${ }^{41} \mathrm{E}$, continua o autor, a emancipação "começa quando se compreende que olhar é também uma ação que confirma ou transforma essa distribuição de posições". ${ }^{42}$ Tal ideia implica em uma reconfiguração do pensamento daquilo que faz a arte ser política ou daquilo que faz de uma imagem uma imagem resistente. Como afirmou-se anteriormente, não se trata de pensar a arte sob a égide do engajamento, que pressupõe, na leitura de Rancière ${ }^{43}$, a passividade e a ignorância do espectador em oposição à atividade e ao desvelamento da verdade intuídos pelo artista. Assim, se a arte tem algo a ver com a utopia, é em um sentido totalmente inverso daquele concebido pelo projeto modernista: assim como os enunciados políticos, a arte devolve à utopia

seu caráter de 'irrealidade', de montagem de palavras e de imagens, próprio para reconfigurar o território do visível, do pensável 
e do possível. As 'ficções' da arte e da política são, portanto, heterotopias mais do que utopias. $^{44}$

Nesse sentido, para apresentarmos a questão sobre as capacidades políticas e de resistência da arte e das imagens a partir do modelo de eficácia estético, ela não deve apresentar um sentido de progresso e de desvelamento da verdade, tampouco qualquer ideia de totalidade; antes, trata-se de pensar a questão a partir da ideia de que, se a arte e as imagens operam algo no real, elas operam uma partilha do sensível, ou, ainda, uma heterotopia. As imagens, como dissemos, dizem respeito às relações entre o visível e 0 invisível, entre o dizível e o indizível. E é operando distâncias entre esses elementos e repartilhando o sensível que ela pode operar uma configuração política. Assim como aproximamos os modelos de eficácia (ética e representativa) da arte engajada à ideia de utopia, aproximaremos, a partir daqui, o modelo de eficácia estética - bem como a noção de partilha do sensível a ele subjacente - à noção de heterotopia.

Pretendemos deslocar as relações entre arte e política a partir de uma série de figuras de imagens heterotópicas, em oposição às imagens utópicas apresentadas. Como afirma Foucault, as heterotopias são "espaços absolutamente outros" ${ }^{45}$, que não existem simplesmente em nossos pensamentos e sonhos, mas, sim, em "um lugar preciso e real, um lugar que podemos situar no mapa; utopias que têm um tempo determinado, um tempo que podemos fixar e medir conforme o calendário de todos os dias". ${ }^{46}$ Uma imagem heterotópica, assim, não seria aquela investida de um projeto de conscientização e ação política, mas, antes, aquela capaz de inserir um pequeno desvio, uma fenda, uma falha na ordenação comum das coisas, transformando o invisível em visível; seria, ainda, aquela capaz de embaralhar os espaços e os tempos e os modos com os quais nos relacionamos com eles; aquela que operaria uma confusão entre os papeis e espaços do artista e do espectador, entre atividade e passividade. Estamos assim mais próximos de pensar o que Rancière propôs como um modelo de eficácia estética da arte, compreendido como um modo de pensamento 
no qual a autonomia do sensível torna possível que qualquer um tenha uma experiência estética, uma experiência suspensiva da ordem do comum. E a forma dessa experiência não é aquela do engajamento ou mesmo a da intervenção direta no real, antes, ela é contingencial e, por isso mesmo, suspensiva. Como afirma Pedro Hussak van Velthen Ramos,

\begin{abstract}
a eficácia estética concerne precisamente à compreensão de que há uma descontinuidade entre as formas sensíveis da produção artística e as formas sensíveis do pensamento dos espectadores. Nesta perspectiva, a politicidade da arte, tal como Rancière pensa, não está na direção do público para determinados fins, mas, ao contrário, na suspensão de toda relação determinável entre a intenção da produção e o efeito na recepção. A arte é política quando produz um dissenso entre a produção artística e fins sociais definidos. ${ }^{47}$
\end{abstract}

Assim, as imagens heterotópicas que buscaremos construir aqui se aproximam do modelo de eficácia estética e da operação de uma partilha do sensível, compreendida como um retraçado das linhas do espaço comum.

\title{
Os vaga-lumes e a escuridão
}

É noite e a escuridão é total. À frente, um campo aberto. 0 único som que se escuta é o do vento que não encontra muita resistência em um lugar tão vazio, a não ser as folhas baixas do chão que balançam. Está tudo só, deserto, escuro, um silêncio quase completo. Não parece haver vida. De repente, uma pequena luz verde brilha próxima ao chão, um pouco mais a frente e logo some. Tem que se apertarem os olhos para procurar esse pequeno brilho que quase parece uma quimera aos olhos acostumados a nada ver. Novamente, a luzinha verde, agora mais próxima. Os olhos começam a piscar mais rápido, com medo de perder outra aparição. Reaparece a luzinha, e mais uma, e outra, ainda. Piscam intermitentemente aqui e ali. Não é apenas uma, então. Quanto mais nossos olhos procuram e se habituam a ver novamente algo além da escuridão, mais luzinhas vão aparecendo, aqui e ali. Como se 
funcionassem por contágio, o número de pontinhos verdes luminosos não para de crescer. 0 campo, antes escuro e vazio, agora brilha uma luz verde que varia o tempo todo, que se move, como uma comunidade de pequenos serezinhos verdes a se moverem em um salão de dança. Seu movimento faz "suspeitar de algo como uma reunião de espectros em miniatura, seres bizarros com mais, ou menos, boas intenções" ${ }^{48}$ Ou será que se movem como em uma revolução? Como manifestantes que tomam as ruas e ateiam fogo a tudo que encontram pelo caminho para mostrar que, em meio à escuridão, suas vidas pulsam ainda?

Didi-Huberman, em seu livro Sobrevivência dos vaga-lumes, persegue - como perseguimos aqui nossas imagens heterotópicas - a aparição desses seres que emanam uma lucciole (pequena luz) em oposição à luce (grande luz) dos holofotes de controle e dominação que iluminam cada mínimo espaço da vida em sociedade. Didi-Huberman nos apresenta a ideia dos vaga-lumes a partir de uma carta escrita por Pier Paolo Pasolini, em 1941, endereçada a um amigo de infância. Em meio aos horrores da Segunda Guerra e ao fascismo que cresce na Itália e na Alemanha, Pasolini parece ter se tornado incapaz de enxergar qualquer pequena luz, qualquer vaga-lume capaz de brilhar nesse ambiente de terror e violência. Como escreve Didi-Huberman, salpicando em sua escrita alguns termos usados por Pasolini,

\begin{abstract}
é um tempo em que os 'conselheiros pérfidos' estão em plena glória luminosa, enquanto os resistentes de todos os tipos, ativos ou 'passivos', se transformam em vaga-lumes fugidios tentando se fazer tão discretos quanto possível, continuando ao mesmo tempo a emitir sinais. ${ }^{49}$
\end{abstract}

Didi-Huberman relata como a carta de Pasolini coloca em tensão dois sentimentos opostos: o da alegria dos pequenos encontros e o do terror inquisidor. 0 poeta fala da amizade, do encontro no escuro em um vasto campo no qual veem, ele e um amigo, uma multidão de vaga-lumes. Mas termina a carta falando de como tiveram que fugir ao verem, nas palavras de 
Didi-Huberman, um "raio inquisidor de dois projetores e o latido assustador de cães de guarda da noite". ${ }^{50} \mathrm{~A}$ dança dos vagalumes que, para Didi-Huberman, perpassaria toda a obra de Pasolini, parecia, nesse momento, ter um fim: "Ele [Pasolini] praticamente teorizou ou afirmou, como uma tese histórica, o desaparecimento dos vaga-lumes". ${ }^{51}$

0 que significa, afinal, que os vaga-lumes tenham desaparecido? É claro que Pasolini, tanto quanto DidiHuberman, estão escrevendo e pensando a política. Mas não se trata somente de pensar a política de Estado - o fascismo institucionalizado pelo governo de Benito Mussolini na Itália mas, também, de uma outra política - aquela que determina nossos modos de vida, que apaga e acende as luzes criando ou retirando as condições de possibilidade de que as pequenas luzes, de que os lampejos de vida apareçam ainda. A imagem criada por Pasolini se insere em um contexto crítico que, como afirma Didi-Huberman, estava associado não apenas ao genocídio da guerra, mas, também, àquele outro que Pasolini denominava de genocídio cultural: nas palavras de DidiHuberman, "aquele que tem por alvo os valores, as almas, as linguagens, os gestos, os corpos do povo".$^{52}$ Trata-se, assim, de uma crítica à dita sociedade de consumo, como se esta tivesse restado como efeito nefasto do fascismo, como se a indiferença da guerra tivesse se transformado em mercadoria. ${ }^{53}$ Pasolini, segundo a interpretação de DidiHuberman ${ }^{54}$, teria afirmado um empobrecimento da experiência sensível como consequência da guerra mas, também, como efeito do poder do consumo que teria deformado a consciência do povo italiano.

Didi-Huberman, porém, questiona o pessimismo de Pasolini ao afirmar que "uma coisa é designar a máquina totalitária, outra coisa é lhe atribuir tão rapidamente uma vitória definitiva e sem partilha". ${ }^{55}$ Didi-Huberman opera um desvio em relação à tradição crítica que, acreditamos, nos possibilitará aproximá-lo do pensamento de Rancière. A imagem, para Didi-Huberman, não é alienante por si só. Não se trata de compreendê-la como mais um produto da indústria cultural. Antes, trata-se de pensá- 
la a partir de um movimento dialético que coloca as imagens em relação, bem como nosso olhar em relação com elas. É isso que está em jogo na crítica que Didi-Huberman faz a Pasolini por ter decretado o desaparecimento dos vaga-lumes:

Seria bem mais justo dizer que eles 'se vão', pura e simplesmente. Que eles 'desaparecem' apenas na medida em que o espectador renuncia a segui-los. Eles desaparecem de sua vista porque o espectador fica no seu lugar que não é mais o melhor lugar para vêlos. ${ }^{56}$

Assim, compreendemos como a imagem, para Didi-Huberman, não é o mal de uma sociedade dominada pela lei do consumo. A imagem dialoga com nossa capacidade política, já que a imaginação é um "mecanismo produtor de imagens para o pensamento" ${ }^{57}$ Didi-Huberman refere-se, assim, a Rancière: "E não nos espantemos de que a extensa reflexão política empreendida por Jacques Rancière devesse, a certo momento crucial de seu desenvolvimento, se concentrar em questões de imagem, de imaginação e de 'partilha do sensível'". ${ }^{58} \mathrm{~A}$ imagem, afinal, para ambos os autores, faz parte da imaginação política e da partilha do sensível. Corroborando tal visão, Hussak v.V. Ramos afirma que

Rancière não vê qualidades particulares intrínsecas às imagens que seriam dadas pelo meio técnico que as produziu, mas busca, antes, compreendê-las dentro de um sistema de relações a priori que define o seu modo de apresentação. Tais sistemas constituem um regime de imagéité, cujo modo de articulação define sua politicidade específica. ${ }^{59}$

Nesse terreno da imagem e da imaginação política, que é também espaço da partilha do sensível, Didi-Huberman aponta aquilo que compreende como o terror:

não foi na noite que os vaga-lumes desapareceram, com efeito. Quando a noite é mais profunda, somos capazes de captar o mínimo clarão, e é a própria expiração da luz que nos é ainda mais visível em seu rastro, ainda que tênue. Não, os vaga-lumes desapareceram na ofuscante claridade dos 
'ferozes' projetores: projetores dos mirantes, dos shows políticos, dos estádios de futebol, dos palcos de televisão. ${ }^{60}$

O terror não está na escuridão, mas sim no clarão que não deixa nenhuma sombra, nenhum espaço que não esteja completamente iluminado. O terror está no controle de cada mínimo indivíduo, de cada mínimo gesto, de cada espaço, tornando impossível qualquer outro modo de vida que não seja aquele da regra. Para Rancière, a regra é a ordenação de nossos modos de vida a partir daquilo que denomina de razão policial - uma forma de pensamento que atua na partilha do sensível ao situar

os corpos em seu lugar e nas suas funções segundo suas 'propriedades', segundo seu nome ou sua ausência de nome, o caráter 'lógico' ou 'fônico' dos sons que saem de sua boca. 0 princípio desse estar-junto é simples: dá a cada um a parcela que the cabe segundo a evidência do que ele é. As maneiras de ser, as maneiras de fazer e as maneiras de dizer ou de não dizer - aí remetem exatamente umas às outras. ${ }^{61}$

Fazendo dialogar Didi-Huberman com Rancière, pode-se pensar que a regra que ordena nossos modos de vida é aquela que configura um regime de visibilidade no qual nada pode escapar à luz. Sob a razão policial ou sob a luz forte dos projetores, nossos modos de aparecer no mundo têm que concordar com aquilo que somos - como se se tratasse de uma essência inapagável. Os espaços de pouca luz - nos quais se fazem reuniões conspiratórias contra o poder, nos quais os amigos se encontram para beber e se alegrar, onde os casais vão para se amar, onde novas ideias e modos de ser surgem e convivem escapando às luzes condenatórias - não podem existir quando a partilha do sensível opera uma razão policial. Afinal, tudo aquilo que rasteja pelos lugares escondidos da cidade está, ou pode vir a tornar-se, a exceção, o excesso que deve ser extirpado para que tudo volte a ficar em seu lugar, para que tudo volte a ficar às claras novamente. Tudo se passa como se diante da luz total, que não deixa sombras, a única aparição fosse a da regra, pois as pequenas luzes dos vaga-lumes, em 
sua fragilidade e intermitência, só podem ser vistas nas zonas de sombra e escuridão.

$$
\begin{aligned}
& \text { Assim, a vida dos vaga-lumes parecerá } \\
& \text { estranha e inquietante, como se fosse feita da } \\
& \text { matéria sobrevivente - luminescente, mas } \\
& \text { pálida e fraca, muitas vezes esverdeada - dos } \\
& \text { fantasmas. Fogos enfraquecidos ou almas } \\
& \text { errantes. }^{62}
\end{aligned}
$$

Pequenas e frágeis luzes em oposição às luzes totais, à claridade completa. Essa é a imagem de resistência que DidiHuberman concebe, ou, ainda, a imagem heterotópica que buscamos construir em oposição às imagens utópicas.

Didi-Huberman ${ }^{63}$ parece inverter a lógica de um pensamento de que as resistências políticas somem em tempos sombrios. Afinal, o autor afirma que é exatamente nas sombras, na escuridão, que podemos ver essas resistências mínimas. É disso que se trata também para Rancière ${ }^{64}$, para quem a mudança no regime de visibilidade das artes ocorrida com a literatura romanesca no século XIX teria configurado um modo de visibilidade e pensabilidade no qual as pessoas quaisquer, os anônimos, teriam surgido como imagem da resistência a uma ordenação policial da sociedade. Como afirma Rancière, o regime do modelo de eficácia estética é aquele da revolução estética, é "antes de tudo a glória do qualquer um". ${ }^{65}$ As pessoas quaisquer, esses anônimos aos quais se refere Rancière, em suas vidas sem importância, é que aparecem como figuras da resistência, como pequenos pontos luminosos que se encontram e brilham nas noites mais escuras. Questão de visibilidade, de partilha do sensível. 


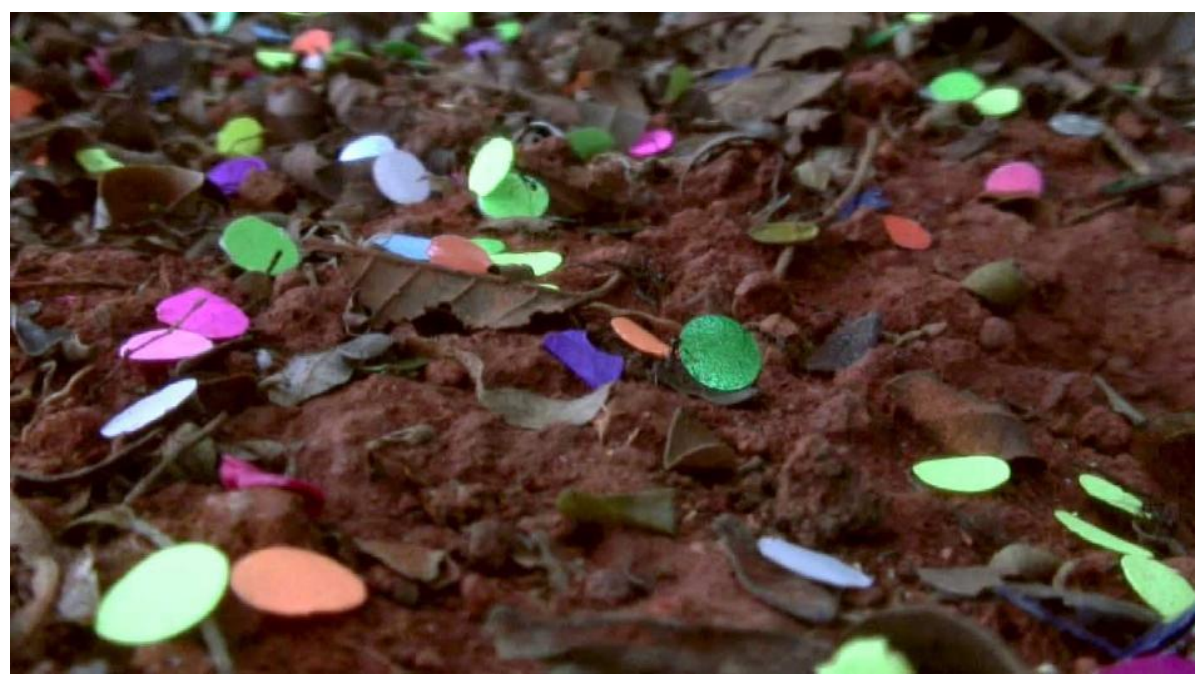

R. Neuenschwander e C. Guimarães, Quarta-feira de cinzas, 2006.

Se pudermos, assim, a partir de Rancière, Foucault e DidiHuberman, pensar imagens heterotópicas, elas serão imagens capazes ainda de produzir pequenos pontos luminosos em meio ao excesso de luz. Como aqueles que vemos na videoarte Quarta-feira de cinzas / Epílogo de Rivane Neuenschwander e Cao Guimarães, na qual pequenas formigas são filmadas de perto, em uma trilha em um chão de floresta, carregando em suas costas pequenos círculos de papel colorido, como confetes de carnaval. Esses pequenos pontos coloridos emitem um brilho de cor em meio aos tons marrons da terra e das folhas no chão. Aquilo que para as formigas é um imenso mundo, maior que seus próprios corpos, para nós são apenas pequenos pontos de luz, mas capazes de alegrar, de colorir a vida, ainda, mesmo quando o carnaval termina em uma triste quarta-feira de cinzas. Para essas formigas, pequenas existências invisíveis, as cores do carnaval nunca vão embora; elas as carregam consigo ainda após aquilo que para muitos é o fim, pois sabem que nada desaparece por completo. Assim também pensamos a política a partir de Didi-Huberman, Rancière e Foucault: não se trata do pensamento de um grande plano futuro, de um projeto total ou de uma utopia, mas, sim, de existências mínimas e anônimas que, por caminharem fora das luzes ou desviando a razão policial, podem fazer surgir uma outra configuração espaço-temporal, uma outra partilha do sensível. As formigas que carregam confetes ou os vaga-lumes que iluminam fracamente uma noite de verão expressam essa 
noção que vamos construindo de imagens heterotópicas, imagens que fogem à regra, desviando a ordenação política e social dos corpos.

Trata-se de pensar - se concordarmos com o diagnóstico de um domínio da razão policial (pensada por Rancière) e da sociedade de controle (que Didi-Huberman ${ }^{66}$ afirma ter sido pensada por Foucault e Gilles Deleuze) - se, como questiona Ricardo Fabbrini, "é possível, ainda, produzir uma imagem que detenha algum enigma, que indicie algum segredo, mistério ou recuo". ${ }^{67}$ Se existe, ainda, alguma imagem que resista, alguma imagem heterotópica.

Rancière ${ }^{68}$, em diálogo direto com a exposição Levantes de Didi-Huberman, afirma, no catálogo da exposição, que a palavra levante é uma daquelas que parecem já indicar o caminho entre as palavras e as coisas, como se, nela, essa distância fosse menor do que em outras palavras. Afinal, continua Rancière,

o que, no mundo, não se levanta? É no que a vida se reconhece: a pulsação sob a pele, a respiração que imperceptivelmente levanta $o$ lençol, o vento que move tanto a poeira, símbolo do nada, quanto a onda, símbolo de tudo, representando a calma da movimentação regular ou a explosão da tempestade. Como então não incluir, na grande respiração da vida que se levanta, o momento em que ondas de populações, cujo sopro e sangue batiam silenciosamente por trás das paredes de casa, ruidosamente se espalham nas ruas, atrás de punhos erguidos ou de bandeiras que estalam ao vento? Como não associar o movimento das linhas sobre uma tela pintada e a respiração das frases dos livros à grande continuidade da vida que se levanta? ${ }^{69}$

Rancière sugere, com isso, que as imagens que resistem não possuem uma forma própria ou específica; não possuem fórmula ou método; antes, elas podem surgir da banalidade da vida de indivíduos que simplesmente respiram no interior de suas casas ou de uma massa de pessoas que tomam o espaço público em revolta. A imagem heterotópica pode configurar-se no vazio dos espaços e dos tempos, nos objetos úteis ou 
inúteis. Não há tema, pessoa, espaço, objeto ou forma de expressão que seja maior ou mais importante em uma hierarquia que determinaria a eficácia da política. Afinal, para Ranciére $^{70}$, a única coisa própria à política é a contingência. $E$, se e quando ela surge, não se sabe como terá início, tampouco que forma configurará. Do mesmo modo, a razão policial que ofusca nossos olhos com os projetores é pura contingência. 0 que significa pensar que nenhum estado de coisas é fixo ou imutável, que nenhum tempo sombrio pode ser visto como definitivo. É essa, também, a crítica que Didi-Huberman ${ }^{71}$ dedica à teoria do desaparecimento dos vaga-lumes de Pasolini. Afinal, trata-se de treinar os olhos para vê-los, de buscar os lugares onde eles podem surgir novamente, ou onde se escondem enquanto os fachos de luz percorrem o chão em busca dos desviados. Trata-se de procurar a noite para ver vaga-lumes, de olhar para o chão na quarta-feira de cinzas e enxergar os pequenos pontos luminosos que caminham sobre as costas das formigas. 

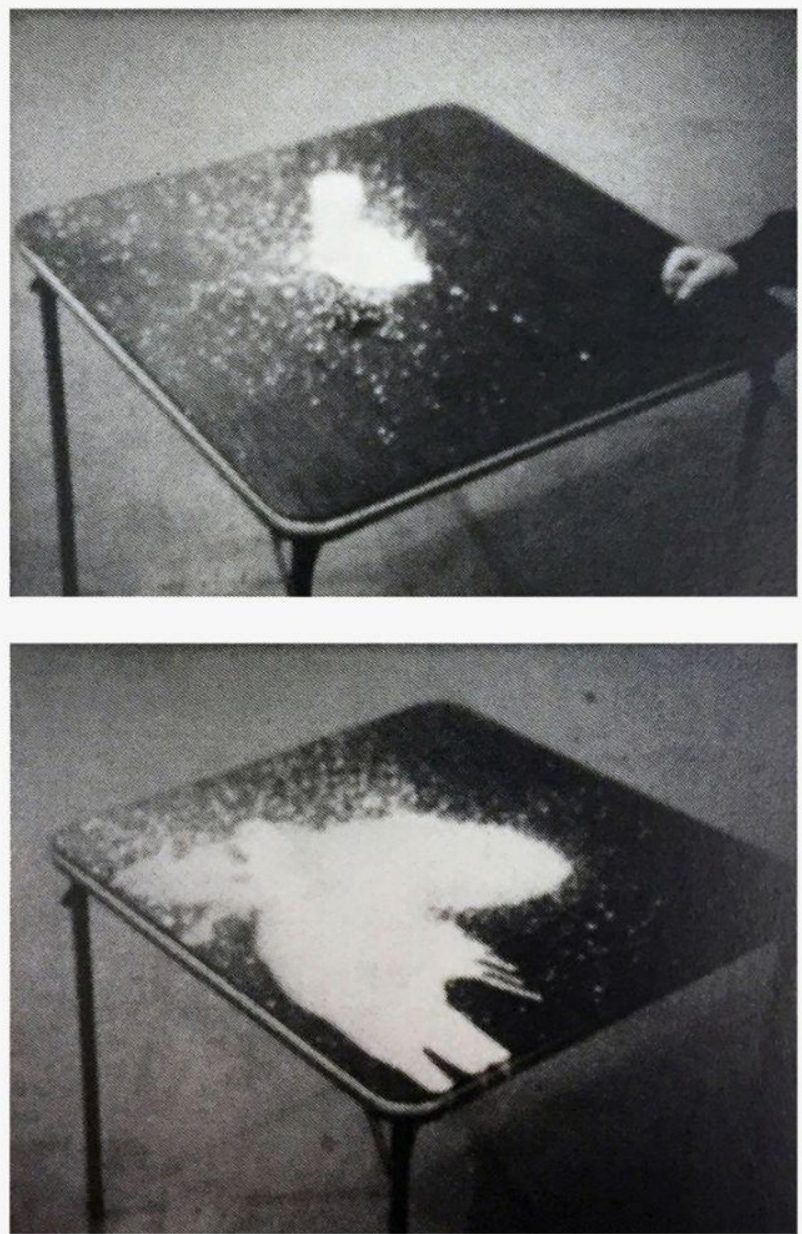

Jack Goldstein, A Glass of Milk, 1972. 
Há uma ideia da persistência do olhar, da insistência de um corpo que busca aquilo que será capaz de afetar-lhe de um modo diverso, mesmo em meio ao controle da luz ofuscante. É nesse estado de persistência do olhar que nos coloca a obra $A$ Glass of Milk, de Jack Goldstein, escolhida por Didi-Huberman para compor sua exposição Levantes ao lado das diversas imagens de multidões e corpos que se levantam e se revoltam contra o poder instituído. No vídeo realizado por Goldstein, vemos um gesto simples ser repetido até a exaustão: um punho fechado que bate contra a superfície de uma mesa na qual encontra-se um copo cheio de leite. A cada batida na mesa, que repete sempre o mesmo ritmo e a mesma força, o copo se move um pouco sobre a superfície da mesa, algumas gotas do líquido branco respingam sobre a mesa escura. Temse a impressão, ao longo de boa parte do vídeo, que dura quatro minutos e quarenta e dois segundos, de que nada irá acontecer. Ao mesmo tempo, espera-se ansiosamente para ver algo acontecer, para ver a imagem se modificar, para ver 0 momento no qual se rompe com o imaginado para que $o$ inesperado surja. E pouco importa, ao fim, o momento no qual o copo vira e derruba todo o leite na mesa. 0 vídeo, como de costume, é exposto em looping, fazendo com que o fim seja, novamente, o princípio, fazendo com que o copo derramado depois de muita persistência, esteja cheio novamente, a mesa limpa, e o gesto repetindo-se novamente. Interessa, mais que o fim do vídeo, o estado no qual se entra, a experiência da persistência do olhar. Aquela de que talvez Pasolini tenha se esquecido ou deixado para trás no momento em que declara o fim dos vaga-lumes. Como afirma Didi-Huberman, nos tempos difíceis, "haverá apenas sinais, singularidades, pedaços, brilhos passageiros, ainda que fracamente luminosos. Vaga-lumes, para dizê-lo da presente maneira". ${ }^{72}$ Os vaga-lumes só desaparecem "na medida em que o espectador renuncia a segui-los". ${ }^{73}$ Assim, como afirma Fabbrini,

é preciso, malgrado as dificuldades, desenvolver a percepção no sentido de permitir-lhe selecionar essas imagens, no reconhecimento de suas diferenças ou singularidades. Seria preciso, por exemplo, 
um aguçamento da sensibilidade para os matizes ou cambiâncias nas imagens. ${ }^{74}$

\section{Considerações finais}

A política e as imagens heterotópicas não surgem em um ambiente específico, não surgem ali onde há espaço e tempo para a alegria, os desvios e a desordem dos corpos cheios de vida; afinal, os espaços e tempos nos quais todos são livres só existem como utopia. É isso que está em jogo nas pequenas luzes que só surgem na escuridão, nos pontos coloridos que podem ser vistos na quarta-feira de cinzas ou, ainda, na persistência do gesto contra o copo de leite que parece, de largada, fadado ao fracasso. Pensar em uma imagem heterotópica significaria, assim, afirmar, como fez DidiHuberman, "que em nosso modo de imaginar jaz fundamentalmente uma condição para nosso modo de fazer política". ${ }^{75}$ Uma imagem heterotópica seria aquela que nos leva para um espaço-tempo impossível que seja possível em nosso mundo atual, como uma reconfiguração da partilha do sensível.

Tanto para Didi-Huberman, quanto para Rancière, não existe um futuro no qual se realizaria um projeto concebido no presente, não existe um outro lugar ou outro tempo no qual as luzes dos projetores e a razão policial desapareceriam, não existe a utopia. Temos, apenas, para viver, o tempo e o espaço que nos circundam e, se algo pode neles ser modificado, é como uma falha ou um desvio que faz surgir, como pequenos pontos de luz, imagens heterotópicas. O que nos restaria, assim, seria a persistência do olhar, o gesto de olhar novamente para os mesmos espaços, de exercer a percepção para que as imagens heterotópicas surjam. Como afirma Rancière, "os únicos que podem afrontar a mediocridade ou a opressão são os que sabem [...] que a mesma situação não cessará de se reapresentar e que é preciso a cada vez agir como se escolhêssemos de uma vez por todas". ${ }^{76}$

Mas, se parece que o que nos resta é um trabalho de Sísifo condenado a levar pela eternidade a enorme pedra de mármore até o ponto mais alto da montanha para vê-la voltar ao ponto 
inicial sempre que se aproximava do cume - podemos pensar em uma outra imagem, menos apocalíptica: aquela de Penélope que, tentando enganar o pai contra um casamento indesejado, prometeu casar-se quando terminasse de tecer um grande manto. Todos os dias, sob a luz do sol e o olhar de todos, tecia o manto correndo o risco de chegar ao fim e ter que cumprir sua promessa, mas, durante a noite, desfazia todo o trabalho feito no dia anterior, fazendo com que o trabalho nunca chegasse a termo. Penélope também sabia que as resistências só podem acontecer na escuridão da noite, quando aqueles que obedecem às regras dormem. $\mathrm{E}$, a cada dia, tecia uma nova trama com os mesmos fios da noite anterior.

\section{Referências bibliográficas}

BOURRIAUD, Nicolas. Estética relacional. Tradução de Denise Bottmann. São Paulo: Martins, 2009.

CALDERÓN, Andrea Soto. "Reivindicación de las apariencias en el trabaljo de Jacques Rancière". Daimon. Revista internacional de filosofía, Murcia, n. 79, (jan-abr, 2020), p. 21-35.

DIDI-HUBERMAN, Georges. Sobrevivência dos vaga-lumes. Tradução de Vera Casa Nova e Márcia Arbex. Belo Horizonte: Editora UFMG, 2014.

FABBRINI, Ricardo. "Imagem e enigma". Viso: Cadernos de estética aplicada, v. X, n. 19, (jul-dez, 2016), p. 241-262.

FOUCAULT, Michel. O corpo utópico, as heterotopias. Tradução de Salma Tannus Michail. São Paulo: n-1 Edições, 2013.

HUSSAK, Pedro. "Rancière: a política das imagens". Princípios, v. 19, n. 32, (jul-dez, 2012), p. 96-107.

HUYSSEN, Andreas. "Mapeando o pós-moderno". In: HOLANDA, Heloísa Buarque. (org.) Pós-modernismo e política. Rio de Janeiro: Rocco, 1991. p. 15-80.

PLATÃo. A república. Organização e tradução de J. Guinsburg. São Paulo: Perspectiva, 2010. 
RANCIÈRE, Jacques. "Prefácio". In: BLANQUI, Auguste. A eternidade pelos astros. Tradução de Takashi Wakamatsu. Desterro (Florianópolis): Cultura e Barbárie, 2017a.

A partilha do sensivel: estética e política. Tradução de Mônica Costa Netto. São Paulo: Ed. 34, 2009.

Malaise dans l'esthétique. Paris: Éditions Galilée, 2004.

O desentedimento: política e filosofia. Tradução de Ângela Leite Lopes. São Paulo: Editora 34, 2018.

. O destino das imagens. Tradução de Mônica Costa Netto. Rio de Janeiro: Contraponto, 2012a.

. O espectador emancipado. Tradução de Ivone C. Benedetti. São Paulo: WMF Martins Fontes, 2012b.

0 mestre ignorante. Tradução de Lílian do Valle. Belo Horizonte: Autêntica, 2010.

The Method of Equality. Tradução de Julie Rose. Cambridge: Polity Press, 2016.

"Um levante pode esconder outro". In: DIDI-HUBERMAN, Georges. Levantes. São Paulo: Edições Sesc São Paulo, 2017b.

Daniela Cunha Blanco é doutoranda em filosofia na USP

* O presente trabalho foi realizado com apoio da Coordenação de Aperfeiçoamento de Pessoal de Nível Superior - Brasil (CAPES) - Código de Financiamento 001.

${ }^{1}$ RANCIÈRE, 2004.

${ }^{2}$ RANCIÈRE, 2009, p. 60.

${ }^{3}$ RANCIÈRE, 2009, p. 16-17.

${ }^{4}$ RANCIÈRE, 2012b.

${ }^{5}$ DIDI-HUBERMAN, 2014.

${ }^{6}$ RANCIÈRE, 2009, p. 62, grifo nosso.

${ }^{7}$ Trata-se de uma característica bastante comum do modo de pensamento e de escrita de Rancière, para quem interessa mais, como afirma, "escolher uma singularidade e então tentar reconstruir as condições que tornam essa singularidade possível explorando todas as teias de significados tecidas em 
torno dela" (RANCIÈRE, 2016, p. 67, tradução nossa). Há, portanto, em seu método, uma certa característica contingencial e as construções de conceitos vão aparecendo de acordo com a singularidade sobre a qual se debruça, ora retornando - como no caso da noção de partilha do sensível, ora aparecendo de maneira pontual, tal qual é o caso da noção de heterotopia. Questionado sobre sua compreensão do que são os conceitos para o pensamento e a filosofia, o autor responde: "Eu não penso que os conceitos sejam como noções que se encaixam para constituir um sistema. Eles são substantivos que designam um modo de abordagem, um método, e que esboçam um terreno de pensamento e sugerem modos de nos orientarmos nesse terreno" (RANCIÈRE, 2016, p. 84, tradução nossa).

${ }^{8}$ FOUCAULT, 2013.

${ }^{9}$ RANCIÈRE, 2012b.

${ }^{10}$ RANCIÈRE, 2012b, p. 58.

${ }^{11}$ RANCIÈRE, 2012b, p. 15.

${ }^{12}$ RANCIÈRE, 2012b, p. 18.

${ }^{13}$ HUYSSEN, 1991, p. 15-80.

${ }^{14}$ FOUCAULT, 2013, p. 19.

${ }^{15}$ RANCIÈRE, 2012b, p. 52.

${ }^{16}$ RANCIÈRE, 2012b, p. 29-30

${ }^{17}$ RANCIÈRE, 2012b.

${ }^{18}$ RANCIÈRE, 2012b

${ }^{19}$ RANCIÈRE, 2012b, p. 31.

${ }^{20}$ RANCIÈRE, 2012b, p. 31.

${ }^{21}$ RANCIÈRE, 2012b, p. 32.

${ }^{22}$ RANCIĖRE, 2012b, p. 68.

${ }^{23}$ Bourriaud, no livro Estética relacional, define a arte relacional como aquela que "toma como horizonte teórico a esfera das interações humanas e seu contexto social mais do que a afirmação de um espaço simbólico autônomo e privado" (BOURRIAUD, 2009, p. 19). Para o autor e curador, a intersubjetividade e o estar-juntos são tema central da arte relacional cujo intuito, em suas palavras, é a construção coletiva de sentido. No livro em questão, há uma série de análises de obras cujas características replicam o pensamento da arte relacional e para as quais o autor afirma operarem "utopias de proximidade" (BOURRIAUD, 2009, p. 13).

${ }^{24}$ RANCIÈRE. 2012b, p. 67.

${ }^{25}$ Rancière associa essa construção harmoniosa da comunidade à Platão, responsável, diz o autor, por inventar "o regime de interioridade da comunidade, no qual a lei é a harmonia do ethos, a concordância do caráter dos indivíduos aos costumes da coletividade" (RANCIÈRE, 2018, p. 82).

${ }^{26}$ RANCIÈRE. 2012b, p. 70. 
${ }^{27}$ RANCIÈRE, 2012 b, p. 71.

${ }^{28}$ RANCIÈRE, 2012b.

${ }^{29}$ RANCIĖRE, 2012b, p. 71.

${ }^{30}$ CALDERÓN, 2020, p. 22, tradução nossa.

${ }^{31}$ RANCIĖRE, 2012b, p. 52.

${ }^{32}$ CALDERÓN, 2020, p. 25, tradução nossa.

${ }^{33}$ CALDERÓN, 2020, p. 26, tradução nossa.

${ }^{34}$ RANCIÈRE, 2012.

${ }^{35}$ RANCIĖRE, 2012b, p. 58.

${ }^{36}$ RANCIĖRE, 2012b, p. 58.

${ }^{37}$ RANCIÈRE, 2012a, p. 22.

${ }^{38}$ RANCIÈRE, 2012a, p. 12-13.

${ }^{39}$ RANCIĖRE, 2012a, p. 13.

${ }^{40}$ RANCIÈRE, 2009, p. 61.

${ }^{41}$ RANCIÈRE, 2012b, p. 23.

${ }^{42}$ RANCIÈRE, 2012b, p. 17.

${ }^{43}$ RANCIÈRE, 2012b.

${ }^{44}$ RANCIÈRE, 2009, p. 62.

${ }^{45}$ FOUCAULT, 2013, p. 21.

${ }^{46}$ FOUCAULT, 2013, p. 19.

${ }^{47}$ HUSSAK, 2012, p. 103.

${ }^{48}$ DIDI-HUBERMAN, 2014, p. 14.

${ }^{49}$ DIDI-HUBERMAN, 2014, p. 17.

${ }^{50}$ DIDI-HUBERMAN, 2014, p. 21.

${ }^{51}$ DIDI-HUBERMAN, 2014, p. 25.

${ }^{52}$ DIDI-HUBERMAN, 2014, p. 29

${ }^{53}$ DIDI-HUBERMAN, 2014.

${ }^{54}$ PASOLINI, P. apud DIDI-HUBERMAN, 2014.

${ }^{55}$ DIDI-HUBERMAN, 2014, p. 42.

${ }^{56}$ DIDI-HUBERMAN, 2014, p. 47.

${ }^{57}$ DIDI-HUBERMAN, 2014, p. 61.

${ }^{58}$ DIDI-HUBERMAN, 2014, p. 61.

${ }^{59}$ HUSSAK, 2012, p. 99.

${ }^{60}$ DIDI-HUBERMAN,2014, p. 30.

${ }^{61}$ RANCIÈRE, 2018, p. 40. 
${ }^{62}$ RANCIÈRE, 2018, p. 14.

${ }^{63}$ DIDI-HUBERMAN, 2014.

${ }^{64}$ RANCIÈRE, 2009.

${ }^{65}$ RANCIÈRE, 2009, p. 48.

${ }^{66}$ DIDI-HUBERMAN, 2014

${ }^{67}$ FABBRINI, 2016, p. 248.

${ }^{68}$ RANCIÈRE, 2017b.

${ }^{69}$ RANCIĖRE, 2017b, p. 63.

${ }^{70}$ RANCIÈRE, 2018.

${ }^{71}$ DIDI-HUBERMAN, 2014.

${ }^{72}$ DIDI-HUBERMAN, 2014, p. 43.

${ }^{73}$ DIDI-HUBERMAN, 2014, p. 47.

${ }^{74}$ FABBRINI, 2016, p. 253.

${ }^{75}$ DIDI-HUBERMAN, 2014, p. 60-61.

${ }^{76}$ RANCIÈRE, 2017a, p. 20. 